\title{
Impact of Incentive Schemes on Employee Performance: A Case Study of Singareni Collieries Company Limited, Kothagudem, Andhra Pradesh, India
}

\author{
Sravan Kumar Reddy and Sarfraz Karim
}

Department of Management, College of Business and Economics, Wollega University, Post Box No: 395, Nekemte, Ethiopia

\begin{tabular}{|c|c|}
\hline & Article Information \\
\hline \multirow{4}{*}{$\begin{array}{l}\text { This paper aims to identify the impact of incentive schemes on factors that affect } \\
\text { employee performance. The researcher identified three categories of employees } \\
\text { of Singareni Collieries Company Limited such as workers, clerical staff and } \\
\text { supervisory staff. The study explores the impact of incentives on several factors } \\
\text { like motivation, absenteeism, employee turnover, production and productivity, } \\
\text { employee morale, health and working conditions, team work, rewarding and work } \\
\text { satisfaction of employees. The data were collected through questionnaire from } \\
120 \text { respondents of all categories. The data analysis were done based on the } \\
\text { mean score, independent sample z-test was used to find any difference exist } \\
\text { among employees in pursuing incentive schemes, findings and conclusions were } \\
\text { drawn from all the three categories of employees. On the whole general } \\
\text { satisfaction is found among all categories of employees. The overall analysis } \\
\text { revealed that incentives schemes are giving satisfactory results in improving } \\
\text { employee performance apart from increasing incomes of the workers and other } \\
\text { benefits. }\end{array}$} & Article History: \\
\hline & $\begin{array}{ll}\text { Received }: 26-09-2013 \\
\text { Revised }: 20-12-2013 \\
\text { Accepted : } 23-12-2013\end{array}$ \\
\hline & $\begin{array}{l}\text { Keywords: } \\
\text { Absenteeism } \\
\text { Incentive } \\
\text { Motivation } \\
\text { Performance } \\
\text { Reward } \\
\end{array}$ \\
\hline & $\begin{array}{l}\text { Sravan Kumar Reddy } \\
\text { E-mail: } \\
\text { sravankumarreddy.ch@gmail.com }\end{array}$ \\
\hline
\end{tabular}

\section{INTRODUCTION}

As competitive pressures mount, organizations are compelled to consider strategies that will help them become more innovative, productive, and efficient. Considering the need to remain competitive, innovative compensation strategies such as incentive programs are often developed in an attempt to align individual motivation and goals with the objectives of the organization. Tully (1995) pointed out that employees are sensing an increased level of anxiety, since they might not know from one year to the next whether they will receive compensation increase or even have a job. There is some indication that companies utilize incentive programs for more than just increasing productivity. Even though the level of socio-economic development varies; in most of developing countries the majority of societies' social and economic conditions are weak (Diriba, 2013). Bencivenga (1997) acknowledges the notion among some experts that incentive programs are also being used to offset wage stagnation and to avoid layoffs during profitable periods. Ichniowski, Shaw, and Prennushi (1997) expanded the examination of the impact of incentive programs on productivity by looking at productivity in conjunction with other innovative work practices including flexible job assignments, employment security and teams. Their finding was that cluster of complementary HR (Human
Resource) practices had a positive impact on output. Creating pay programs that truly reward performance is also one of the six complementary Human resource practices that firms utilize (Cantoni, 1997). Bencivenga (1997) suggests that companies are enhancing performance and becoming more profitable by creating internal cultures of ownership. Banker, Lee and Potter (1996) set out to examine the impact that contextual factors such as competitive intensity, customer focused strategy and behaviour based control had on an outcome based incentive plan focussing on customer service.

Bailey, Brown and Cocco (1998) examine the impact of piece-rate and goal-contingent incentives, versus Fixed-pay found that both overall and initial performance, but not improvement rate, are higher in the incentive-pay groups. Al-Harthi (1999) investigates the relationship of financial and moral incentives to raise the efficiency of employees in the Department of Civil Defense in Riyadh, Saudi Arabia. He found that financial and moral incentives are unsatisfactory and may lead to a decrease in the level of performance of employees. Angari (1999) conducted a field study on incentive and its role in raising the level of employee performance in Riyadh, Saudi Arabia. The results showed that there was no satisfaction for financial 


\section{Sravan Kumar Reddy and Sarfraz Karim}

and moral incentives. Alwabel (2005) investigates the role of financial and moral incentives in raising the performance level of results showed that there are no incentives standards provided to the officers but the degree of their satisfaction is very high. A Study of Individual Incentives versus Team Performance: Lessons from a Game of Charades (Shawn, Patricia and Marlon, 2007) describe a modified game of Charades that was developed to facilitate a discussion on the basic principles of effective reward system design. Students are organized into small groups. Abang, May-Chiun and Maw (2009) found that firm performance has important implications for employees and the impact of incentives on manufacturing companies in the Malaysia context. Koonmee (2010) discusses development of organizational Justice in Incentive allocation of the Thai Public Sector found that distributive justice and procedural justice played more important roles in predicting incentive satisfaction and job performance in 2008 than in 2006. Schmidt (2010) highlights the importance of incentives as determinants of employee performance.

The objective of the study is to assess the impact of Incentive schemes on Employee performance, more specifically, to assess the impact of incentives on productivity, work motivation, absenteeism, turnover, employee morale, rewarding the efficient employee, Health related problems and team work. It also emphasis on examine satisfaction levels of workers and employees about incentive schemes implemented; to examine is there any significant differences exist in benefitting from incentive schemes among workers, clerical staff, and supervisor. And finally to suggest measures to improve incentive system.

\section{MATERIALS AND METHODS}

\section{Research Design}

This study considers the opinions of the three categories of employees at Singareni Collieries Company Limited. The data were collected and coded. The quantitative analyses were performed using SPSS 17.01 (Statistical Package for the Social Sciences) for windows. Descriptive statistics were used to compute mean and weighted mean scores to reveal the impact of wage incentive schemes, independent sample z-test were used in the analysis for testing of differences between means among employees.

\section{Data Sources}

The study is based on both primary data and secondary data. The main sources of primary data include workers, employees, managers and supervisors of selected mines in Singareni Collieries Company Limited. The secondary data is collected from the records and documents of Singareni Collieries Company Limited, annual reports of coal mining industry and other publications of Government and non-Government including Internet sources.

\section{Sampling Procedure and Sample Size}

The following formula was use to determine sample size at $95 \%$ confidence level, level of confidence measure is 1.96; baseline level of indicators 0.5 , an estimated expected response rate of 0.8 among all levels of employees with level of precision is 0.08 .
Sci. Technol. Arts Res. J., Oct-Dec 2013, 2(4): 122-125

$$
\mathrm{n}=\mathrm{Z}^{2} \mathrm{pq} / \mathrm{E}^{2} \quad \text {, }
$$

where $n=$ desired sample size, the value is approximately equal to 120 sample. For the purpose of selecting sample of workers, supervisors and clerical staff at Singareni Collieries Company Limited, a stratified random sampling method was adopted, a sample of 120 respondents were selected proportionately from all the three categories and a simple random sample was adopted to select the proportion of respondents from each category.

\section{RESULTS}

Results of the study made an attempt to examine the opinions of workers, supervisors and clerical staff on various factors that influence employee performance. For this purpose, A questionnaire has been designed and administered on sample respondents. The results are Figure1 shows the profile of the sample respondents, table 1 shows the impact of incentives on work motivation, table 2 shows impact of wage incentives on absenteeism, table 3 shows relation of wage incentives to employee turnover, table 4 shows impact of incentives on productivity where as table 5 shows impact of incentives on employee morale, table 6 shows the impact of incentive schemes on health, table 7 shows the impact of incentives on team work, table 8 shows the impact of incentives on rewarding an employee and table 9 shows impact of incentive schemes on work satisfaction.

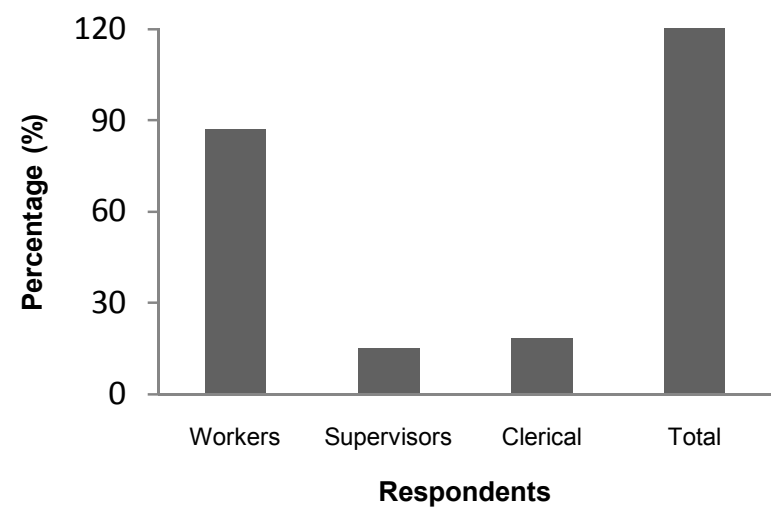

Figure 1: Sample Respondents - Category wise.

Table 1: Impact of incentive schemes on work motivation.

\begin{tabular}{cccc}
\hline Category & $\begin{array}{c}\text { Number of } \\
\text { respondents }\end{array}$ & $\begin{array}{c}\text { Weighte } \\
\text { d scores }\end{array}$ & $\begin{array}{c}\text { Mean } \\
\text { score }\end{array}$ \\
\hline Workers & 87 & 374 & 4.3 \\
Clerical staff & 18 & 82 & 4.5 \\
Supervisors & 15 & 65 & 4.4 \\
\hline Total & $\mathbf{1 2 0}$ & $\mathbf{5 2 1}$ & $\mathbf{4 . 4}$ \\
\hline
\end{tabular}

Table 2: Impact of Incentive Schemes on absenteeism.

\begin{tabular}{lccc}
\hline \multicolumn{1}{c}{ Category } & $\begin{array}{c}\text { Number of } \\
\text { respondents }\end{array}$ & $\begin{array}{c}\text { Weighted } \\
\text { scores }\end{array}$ & $\begin{array}{c}\text { Mean } \\
\text { score }\end{array}$ \\
\hline Workers & 87 & 391 & 4.5 \\
Clerical staff & 18 & 81 & 4.5 \\
Supervisors & 15 & 68 & 4.5 \\
\hline \multicolumn{1}{c}{ Total } & $\mathbf{1 2 0}$ & $\mathbf{5 4 0}$ & $\mathbf{4 . 5}$ \\
\hline
\end{tabular}


Sravan Kumar Reddy and Sarfraz Karim

Table 3: Impact of Incentive Schemes on employee turnover.

\begin{tabular}{lccc}
\hline Category & $\begin{array}{c}\text { Number of } \\
\text { respondents }\end{array}$ & $\begin{array}{c}\text { Weighted } \\
\text { scores }\end{array}$ & $\begin{array}{c}\text { Mean } \\
\text { score }\end{array}$ \\
\hline Workers & 87 & 187 & 2.1 \\
Clerical staff & 18 & 34 & 1.9 \\
Supervisors & 15 & 30 & 2.0 \\
\hline \multicolumn{1}{c}{ Total } & $\mathbf{1 2 0}$ & $\mathbf{2 5 1}$ & $\mathbf{2 . 1}$ \\
\hline
\end{tabular}

Table 4: Impact of Incentive Schemes on improving productivity.

\begin{tabular}{lccc}
\hline Category & $\begin{array}{c}\text { Number of } \\
\text { respondents }\end{array}$ & $\begin{array}{c}\text { Weighted } \\
\text { scores }\end{array}$ & $\begin{array}{c}\text { Mean } \\
\text { score }\end{array}$ \\
\hline Workers & 87 & 418 & 4.8 \\
Clerical staff & 18 & 83 & 4.6 \\
Supervisors & 15 & 71 & 4.7 \\
\hline \multicolumn{1}{c}{ Total } & $\mathbf{1 2 0}$ & $\mathbf{5 6 4}$ & $\mathbf{4 . 7}$ \\
\hline
\end{tabular}

Table 5: Impact of Incentive Schemes on employee morale.

\begin{tabular}{lccc}
\hline Category & $\begin{array}{c}\text { Number of } \\
\text { respondents }\end{array}$ & $\begin{array}{c}\text { Weighted } \\
\text { scores }\end{array}$ & $\begin{array}{c}\text { Mean } \\
\text { score }\end{array}$ \\
\hline Workers & 87 & 339 & 3.9 \\
Clerical staff & 18 & 67 & 3.7 \\
Supervisors & 15 & 60 & 4.0 \\
\hline \multicolumn{1}{c}{ Total } & $\mathbf{1 2 0}$ & $\mathbf{4 5 6}$ & $\mathbf{3 . 8}$ \\
\hline
\end{tabular}

Table 6: Impact of Incentive Schemes on Health Category.

\begin{tabular}{lccc}
\hline \multicolumn{1}{c}{ Category } & $\begin{array}{c}\text { Number of } \\
\text { respondents }\end{array}$ & $\begin{array}{c}\text { Weighted } \\
\text { scores }\end{array}$ & $\begin{array}{c}\text { Mean } \\
\text { score }\end{array}$ \\
\hline Workers & 87 & 322 & 3.7 \\
Clerical staff & 18 & 47 & 2.6 \\
Supervisors & 15 & 48 & 3.2 \\
\hline \multicolumn{1}{c}{ Total } & $\mathbf{1 2 0}$ & $\mathbf{4 2 0}$ & $\mathbf{3 . 5}$ \\
\hline
\end{tabular}

Table 7: Impact of Incentive Schemes on Team WorkCategory.

\begin{tabular}{cccc}
\hline Category & $\begin{array}{c}\text { Number of } \\
\text { respondents }\end{array}$ & $\begin{array}{c}\text { Weighted } \\
\text { scores }\end{array}$ & $\begin{array}{c}\text { Mean } \\
\text { score }\end{array}$ \\
\hline Workers & 87 & 340 & 3.9 \\
Clerical staff & 18 & 69 & 3.8 \\
Supervisors & 15 & 68 & 4.5 \\
\hline \multicolumn{1}{c}{ Total } & $\mathbf{1 2 0}$ & $\mathbf{4 8 0}$ & $\mathbf{4 . 0}$ \\
\hline
\end{tabular}

Table 8: Impact of Incentive Schemes on Rewarding.

\begin{tabular}{lccc}
\hline Category & $\begin{array}{c}\text { Number of } \\
\text { respondents }\end{array}$ & $\begin{array}{c}\text { Weighted } \\
\text { scores }\end{array}$ & $\begin{array}{c}\text { Mean } \\
\text { score }\end{array}$ \\
\hline Workers & 87 & 107 & 4.1 \\
Clerical staff & 18 & 76 & 4.2 \\
Supervisors & 15 & 71 & 4.7 \\
\hline \multicolumn{1}{c}{ Total } & $\mathbf{1 2 0}$ & $\mathbf{5 1 6}$ & $\mathbf{4 . 3}$ \\
\hline
\end{tabular}

Table 9: Impact of Incentive Schemes on work Satisfaction.

\begin{tabular}{lccc}
\hline Category & $\begin{array}{c}\text { Number of } \\
\text { respondents }\end{array}$ & $\begin{array}{c}\text { Weighted } \\
\text { scores }\end{array}$ & $\begin{array}{c}\text { Mean } \\
\text { score }\end{array}$ \\
\hline Workers & 87 & 183 & 2.1 \\
Clerical staff & 18 & 45 & 2.5 \\
Supervisors & 15 & 42 & 2.8 \\
\hline \multicolumn{1}{c}{ Total } & $\mathbf{1 2 0}$ & $\mathbf{2 7 6}$ & $\mathbf{2 . 3}$ \\
\hline
\end{tabular}

Sci. Technol. Arts Res. J., Oct-Dec 2013, 2(4): 122-125

Independent Z-Test for Differences between Means

The table 10 represents the differences between means of workers and clerical staff. The calculated Zvalue is in between confidence intervals and the result shows that there is no significant difference between worker category and clerical staff category in adopting wage incentive plans at study site.

Table 10: Z-test for differences between means of workers and clerical staff.

\begin{tabular}{lllc}
\hline & Workers & clerical staff & Test value \\
\hline Mean & 3.71 & 3.6 & \\
\hline Std Deviation & 0.91705 & 0.96264 & \\
\hline z-value & & 0.4449 \\
\hline two-tailed p-value & & 0.6564 \\
\hline 95\% confidence intervals & \\
Upper & & 0.5946 \\
Lower & & -0.3746 \\
\hline
\end{tabular}

Table 11 shows the results of Z-test to test differences between means of workers and supervisory staff. The calculated Z-value is in between confidence intervals and the result shows that there is no significant difference between worker category and supervisory staff category in adopting wage incentive plans at singareni Collieries Company limited.

Table 11: Z-test to test differences between means of workers and supervisory staff.

\begin{tabular}{|c|c|c|c|}
\hline & Workers & supervisory staff & Test value \\
\hline Mean & 3.71 & 3.8 & \\
\hline Std Deviation & 0.91705 & 0.91652 & \\
\hline z-value & & & -0.3512 \\
\hline two-tailed p-ve & alue & & 0.7254 \\
\hline \multicolumn{4}{|c|}{$95 \%$ confidence intervals } \\
\hline Upper & & & 0.4122 \\
\hline Lower & & & -0.5922 \\
\hline
\end{tabular}

\section{DISCUSSION}

The category wise composition of sample respondents shows that majority of respondents $72.5 \%$ are from the workers category. In fact workers are covered under most of the incentive schemes in Singareni Collieries Company Limited. The clerical category consists of $15 \%$ while supervisors constitute $12.5 \%$ in the total sample. Category wise analysis about the impact of incentive schemes on work motivation reveals that there is higher level of agreement among all categories i.e. workers, supervisors, clerical categories about positive impact of incentive schemes on work motivation. All the employees irrespective of their category indicated high level of agreement 4.5 that incentives help in improving workers attendance. An analysis on Workers willingness to stay in the company for long time revealed that employees do not seriously consider incentives as a major reason to stay in the company for longer time. Among various categories, the mean scores varied between 1.9 and 2.1 which indicates less than average level of agreement. They feel that other factors play a major role in their decision to stay in the company for longer period. Analysis on productivity shows that there is high level of agreement among the workers for positive impact of incentives on productivity of the company. The mean scores among different 


\section{Sravan Kumar Reddy and Sarfraz Karim}

categories vary between 4.6 and 4.8 . Relatively workers indicated more agreement than other categories. Analysis of employee morale due to operation of the incentive schemes reveals that there is higher level of agreement among workers, supervisors and clerical staff that incentives help to boost self-confidence. The mean scores among various categories range between 3.7 to 4 the highest in case of supervisors. Analysis shows that there is agreement among all categories that incentives sometimes cause health problems. The mean scores among different category range between 2.6 to 3.7 . Relatively higher level of agreement is indicated in case of workers followed by supervisors and clerical staff. The mean scores among different categories about incentives help in building team work range between 3.8 to 4.5 , the highest is in case of supervisory staff and lowest is in case of clerical staff where workers mean score is identified as 3.9. Analysis higher level of agreement to the statement among all categories the mean scores ranged between 4.1 to 4.7. It indicated that all the level of category agrees on Incentive schemes help to reward the efficient workers. The category wise a response about satisfaction of implementation of incentive schemes shows that workers are relatively less satisfied with the way of implementation mean scores 2.1. Whereas, clerical staff indicated moderate satisfaction and supervisors higher satisfaction of 2.8. The independent sample z-test for difference between workers and clerical staff about performance of incentive schemes revealed that workers and clerical staff at both level were perceiving incentive benefits equally. The independent sample z-test for difference between workers and supervisors about performance of incentive schemes revealed that workers and supervisors at both levels were perceiving incentive benefits equally.

\section{CONCLUSIONS}

The analysis about impact of incentive schemes on attendance revealed that workers, trained employees and more experienced categories felt that incentive schemes help in improve attendance to the workers. All categories of workers expressed that incentives will have favorable impact to make the employees to stay in the company are low. All categories of employees strongly believe that incentives have definitely helping in improving productivity. Workers category and experience category of employees expressed that as a result of incentive payments employees have a tendency of working overtime which causes health problems. Regarding developing team sprit among employees it is found that majority of the employees perceive improvement in team work as a result of individual and group incentives. The analysis on reward revealed that majority employees believed that incentives will help in rewarding efficient workers. An attempt was made to find whether workers and employees are satisfied with implementation of incentive schemes found that highest satisfaction is indicated among supervision staff .The overall analysis by independent sample z-test between workers and clerical staff, between workers and supervisory staff revealed that incentives schemes are giving satisfactory results in improving workers performance apart from increasing incomes of the workers and other benefits. To make the incentive schemes more effective and beneficial to the workers, Clerical staff and supervisors Incentives bonus can be paid on weekly basis instead of paying them
Sci. Technol. Arts Res. J., Oct-Dec 2013, 2(4): 122-125

fortnightly basis. Incentives should be based on shift average production of the team in order to promote team work.

\section{REFERENCES}

Abang, A., May-Chiun, L., and Maw King, L. (2009). Human Resource Practices and Employee performance. Incentives as Moderator. Journal of Academic Research in Economics 1(2): 219-234.

Al-Harthi, D. (1999). Raising the Efficiency of Workers and Relationship with Financial and Moral Incentives: Case study on the Civil Defence Personnel in Riyadh. Master Thesis. Naif Arab Academy for Security Sciences. Riyadh, Saudi Arabia.

Alwabel. A. (2005). The Role of Financial and Moral Incentives on Raising the Performance Level of Employees from the Viewpoint of the Security Officers Involved in the Pilgrimage Season. Master Thesis. Naif Arab University for Security Sciences. Riyadh, Saudi Arabia.

Angari, A. (1999). Incentive systems and their role in raising the level of performance of employees: case study on workers in the Emirate of Riyadh Region. Master Thesis. Naif Arab Academy for Security Sciences. Riyadh, Saudi Arabia.

Bailey, C. D., Brown, L. D., and Cocco, A. F. (1998). The Effects of Monetary Incentives on Worker Learning and Performance in an Assembly Task. Journal of Management Accounting Research 10: 119-131.

Banker, R., Lee, S. and Potter, G. (1996). Contextual analysis of performance impacts of outcome based incentive compensation. Academy of Management Journal 39: 920-948.

Bencivenga, D. (1997). Employee owners help bolster the bottom line. H R Magazine 7:78-83.

Cantoni, C. 1997. Learn to manage pay and performance like an entrepreneur. Compensation and Benefits Review, 29(1): 52-58.

Diriba, S. (2013). Socio economic contributions of micro and small enterprises: the case of Jimma city. Science technology and arts research Journal 2(2):123-134.

Ichniowski, C., Shaw, K. and Prennushi, G. (1997). The effects of human resource management practices on productivity: A study of steel finishing lines. The American Economic Review 87(3): 291-313.

Koonmee, K. (2010). Development of Organizational Justice in Incentive. World Academy of Science, Engineering and Technology (66): 861-867.

Schmidt, R. (2010). Are Incentives the Bricks or the Building? Journal of Applied Corporate Finance 22(1):129-136.

Shawn, E.P., Patricia, D.L. and Marlon, F.S. (2007). Individual Incentives versus Team Performance: Lessons from a Game of Charades. Organization Management Journal (4): 54-68.

Tully, S. (1995). Are you paid enough? Fortune 26: 66-69. 